\title{
Decomposition of Mono-, Di- and Tri-chlorobenzene by Using Basic Molten Salts
}

\author{
Osamu TAKEDA, ${ }^{1) *}$ Daisuke AOKI, ${ }^{2)}$ Yasufumi YOKKA, ${ }^{3)}$ Tsutomu YAMAMURA $^{1)}$ and Yuzuru SATO ${ }^{1)}$ \\ 1) Tohoku University, 6-6-02 Aramaki-Aza-Aoba, Aoba-ku, Sendai, 980-8579 Japan. \\ 2) Formerly Graduate Student, \\ Tohoku University. Now at Dowa Metals and Mining Co., 4-14-1, Soto-kanda, Chiyoda-ku, Tokyo, $102-0021$ Japan. \\ 3) Formerly Graduate Student, Tohoku University. Now at IHI Co., 3-1-1, Toyosu, Koto-ku, Tokyo, $135-8710$ Japan.
}

(Received on March 7, 2012; accepted on May 2, 2012)

\begin{abstract}
The decomposition of simple chlorinated organic compounds comprising benzene derivatives (mono, di and tri-chlorobenzenes) as the imitation substance of polychlorobiphenyls (PCBs) was investigated by using basic molten salts in order to establish a safe, simple and highly efficient decomposition process for PCBs. Chlorobenzen liquid or the solution was injected into basic molten salts $\left(\mathrm{KOH}-\mathrm{K}_{2} \mathrm{CO}_{3}\right.$ or $\mathrm{NaOH}-$ $\mathrm{Na}_{2} \mathrm{CO}_{3}$ ) at 573-973 $\mathrm{K}$ with imitation air, and the residual concentration of chlorobenzenes in the exhaust was measured after the decomposition treatment. The decomposition efficiency reached to very high of $99.9999 \%$ in an optimum condition. The decomposition efficiencies of chlorobenzenes were affected by the flow rate of the air and the initial concentration of chlorobenzen in the gas mixture. The complete destruction for benzene derivatives required excess oxygen condition.
\end{abstract}

KEY WORDS: PCB; waste treatment; decomposition; chlorinated organic compounds; chlorobenzen; basic molten salts.

\section{Introduction}

Since polychlorobiphenyls (PCBs) have strong toxicity, the waste treatment has been desired for a long time. However, the complete treatment has not been realized because PCBs have very tough chemical structure and there is a risk of the formation of dioxins during the waste treatment. ${ }^{1,2)}$ The authors briefly reviewed the background and the problems on the waste treatment processes for PCBs in the previous paper. ${ }^{3)}$ Based on the investigation, the authors carried out fundamental studies for developing a safe, simple and highly efficient waste treatment process by means of basic molten salts. ${ }^{3)}$

The conventional incineration process of halogenated organic compounds emits the by-products containing halogens into the exhaust, which derives the formation of dioxins due to the recombination reaction in the gas phase. ${ }^{4,5}$ On the other hand, the new decomposition process by using molten salts extracts the halogens from the halogenated organic compounds and captures the halogens in the molten salts. Therefore, the process prevents the formation of dioxins.

The advantages of the new decomposition process are summarized as follows: (1) no dioxins are formed by gas/ liquid separation, and only simple harmless compounds $\left(\mathrm{CO}_{2}\right.$ and $\left.\mathrm{H}_{2} \mathrm{O}\right)$ are emitted; (2) operation temperature is considerably lower than that in the incineration, and the temperature control is easy because of the reaction in con-

\footnotetext{
* Corresponding author: E-mail: takeda@material.tohoku.ac.jp DOI: http://dx.doi.org/10.2355/isijinternational.52.1705
}

densed phase; (3) decomposition treatment is carried out at ambient pressure; (4) handling of chlorine absorber (molten salts) is easy compared to reactive chemicals such as metallic sodium. 6 ,7)

In the previous study, the decomposition of simple chlorinated compounds, $\mathrm{CCl}_{4}$ and mono-chlorobenzen, by using basic molten salts were investigated with non-oxidative atmosphere. ${ }^{3)}$ As a result, $\mathrm{CCl}_{4}$ was destructed at the high decomposition efficiency of $99.95 \%$ at relatively low temperature (673-973 K). However, the decomposition efficiency of mono-chlorobenzen was not enough $(97 \%$ at 973 $\mathrm{K})$, which suggested that oxidation is required for complete decomposition of chlorobenzene.

For the systematic study, the benzene derivatives, mono, di and tri-chlorobenzen were selected as an imitation substance of PCBs in this study, and the decomposition was investigated by using basic molten salts under the oxidative atmosphere.

\section{Experimental}

\subsection{Chemicals}

The physical properties of chemicals used in this study are summarized in Table 1. ${ }^{8-14)}$ Monochlorobenzen $\left(\mathrm{C}_{6} \mathrm{H}_{5} \mathrm{Cl},>99 \%\right.$, Wako Pure Chemical Industries Ltd.) and o-dichlorobenzen $\left(\mathrm{C}_{6} \mathrm{H}_{4} \mathrm{Cl}_{2},>98 \%\right.$, Wako Pure Chemical Industries Ltd.) are liquid at room temperature. But as 1,2,3tirchlorobenzen $\left(\mathrm{C}_{6} \mathrm{H}_{3} \mathrm{Cl}_{3},>95 \%\right.$, Wako Pure Chemical Industries Ltd.) is solid, it was then dissolved in an organic solvent, 2,2,4-trimethylpentane (>99\%, Wako Pure Chemical Industries Ltd.) to be subjected to the experiment as a solu- 
Table 1. Physical properties of the chemicals used in this study.

\begin{tabular}{|c|c|c|c|c|c|c|}
\hline Name & $\begin{array}{l}\text { Chemical } \\
\text { formula }\end{array}$ & $\begin{array}{l}\text { Molecular } \\
\text { weight, } \\
M / \mathrm{g} \cdot \mathrm{mol}^{-1}\end{array}$ & $\begin{array}{c}\text { Density } \\
\text { at } 293 \mathrm{~K} \text {, } \\
\rho / \mathrm{Mg} \cdot \mathrm{m}^{-3}\end{array}$ & $\begin{array}{c}\text { Melting } \\
\text { point, } \\
T_{\mathrm{m}} / \mathrm{K}\end{array}$ & $\begin{array}{c}\text { Boiling } \\
\text { point, } \\
T_{\mathrm{b}} / \mathrm{K}\end{array}$ & $\begin{array}{c}\text { Vapor pressure, } \\
p / \mathrm{kPa} \\
\text { at } 298 \mathrm{~K}\end{array}$ \\
\hline Monochlorobenzen & $\mathrm{C}_{6} \mathrm{H}_{5} \mathrm{Cl}$ & 112.6 & $1.106^{\mathrm{a}}$ & $228^{\mathrm{a}}$ & $405^{\mathrm{a}}$ & $1.58^{\mathrm{a}}$ \\
\hline o-Dchlorobenzen & $\mathrm{C}_{6} \mathrm{H}_{4} \mathrm{Cl}_{2}$ & 147.0 & $1.306^{\mathrm{a}}$ & $256^{\mathrm{a}}$ & $454^{\mathrm{a}}$ & $0.18^{\mathrm{a}}$ \\
\hline 1,2,3-Tichlorobenzen & $\mathrm{C}_{6} \mathrm{H}_{3} \mathrm{Cl}_{3}$ & 181.5 & $1.69^{\mathrm{a}}$ & $326^{\mathrm{a}}$ & $494^{\mathrm{a}}$ & $0.028^{\mathrm{a}}$ \\
\hline 2,2,4-Trimethylpentane & $\left(\mathrm{CH}_{3}\right)_{2} \mathrm{CHCH}_{2} \mathrm{C}\left(\mathrm{CH}_{3}\right)_{3}$ & 114.2 & $0.692^{\mathrm{a}}$ & $166^{\mathrm{a}}$ & $372^{\mathrm{a}}$ & $6.49^{\mathrm{a}}$ \\
\hline Potassium hydroxide & $\mathrm{KOH}$ & 56.1 & $2.055^{\mathrm{d}}$ & $677^{\mathrm{b}}$ & $1594^{\mathrm{g}}$ & - \\
\hline Potassium carbonate & $\mathrm{K}_{2} \mathrm{CO}_{3}$ & 138.2 & $2.43^{\mathrm{e}}$ & $1174^{b}$ & - & - \\
\hline Sodium hydroxide & $\mathrm{NaOH}$ & 40.0 & $2.130^{\mathrm{d}}$ & $593^{c}$ & $1828^{g}$ & - \\
\hline Sodium carbonate & $\mathrm{Na}_{2} \mathrm{CO}_{3}$ & 106.0 & $2.533^{\mathrm{f}}$ & $1131^{\mathrm{c}}$ & - & - \\
\hline
\end{tabular}

Table 2. Experimental conditions for decomposition of chlorobenzens.

\begin{tabular}{|c|c|c|c|c|c|c|c|}
\hline $\begin{array}{l}\text { Exp. } \\
\text { series }\end{array}$ & Sample & Molten salt & $\begin{array}{l}\text { Carrier } \\
\text { gas }\end{array}$ & $\begin{array}{l}\text { Flow rate } \\
\text { of carrier gas, } \\
\mathrm{r} / \mathrm{ml} \cdot \mathrm{min}^{-1}\end{array}$ & $\begin{array}{l}\text { Injection rate } \\
\text { of sample } \\
r^{\prime} / \mu 1 \cdot \mathrm{min}^{-1}\end{array}$ & $\begin{array}{c}\text { Immersion depth } \\
\text { of gas nozzle, } \\
h / \mathrm{mm}\end{array}$ & $\begin{array}{c}\text { Temperature, } \\
T / \mathrm{K}\end{array}$ \\
\hline A & $\mathrm{C}_{6} \mathrm{H}_{5} \mathrm{Cl}$ & Not used & $\begin{array}{l}\text { Imitation } \\
\text { air }\end{array}$ & 50 & 5 & - & $723-973$ \\
\hline B & $\mathrm{C}_{6} \mathrm{H}_{5} \mathrm{Cl}$ & $\begin{array}{l}\mathrm{NaOH}-8.3 \mathrm{~mol} \% \mathrm{Na}_{2} \mathrm{CO}_{3} \text {, } \\
\mathrm{KOH}-9.3 \mathrm{~mol} \% \mathrm{~K}_{2} \mathrm{CO}_{3}, \\
\mathrm{KOH}-30 \mathrm{~mol} \% \mathrm{~K}_{2} \mathrm{CO}_{3}\end{array}$ & $\begin{array}{l}\text { Imitation } \\
\text { air }\end{array}$ & 50 & 5 & 50 & $573-973$ \\
\hline $\mathrm{C}$ & $\mathrm{C}_{6} \mathrm{H}_{5} \mathrm{Cl}$ & $\begin{array}{l}\mathrm{NaOH}-8.3 \mathrm{~mol} \% \mathrm{Na}_{2} \mathrm{CO}_{3} \text {, } \\
\mathrm{KOH}-9.3 \mathrm{~mol} \% \mathrm{~K}_{2} \mathrm{CO}_{3}, \\
\mathrm{KOH}-30 \mathrm{~mol} \% \mathrm{~K}_{2} \mathrm{CO}_{3}\end{array}$ & Nitrogen & 50 & 5 & 50 & $573-973$ \\
\hline $\mathrm{D}$ & $\mathrm{C}_{6} \mathrm{H}_{5} \mathrm{Cl}$ & $\mathrm{KOH}-30 \mathrm{~mol} \% \mathrm{~K}_{2} \mathrm{CO}_{3}$ & $\begin{array}{l}\text { Imitation } \\
\text { air }\end{array}$ & $50-400$ & $5-40$ & 50 & 873 \\
\hline $\mathrm{E}$ & $\mathrm{C}_{6} \mathrm{H}_{5} \mathrm{Cl}$ & $\mathrm{KOH}-30 \mathrm{~mol} \% \mathrm{~K}_{2} \mathrm{CO}_{3}$ & $\begin{array}{l}\text { Imitation } \\
\text { air }\end{array}$ & 25 & $2.5-50$ & 50 & 873 \\
\hline $\mathrm{F}$ & $\mathrm{C}_{6} \mathrm{H}_{4} \mathrm{Cl}_{2}$ & $\begin{array}{l}\mathrm{NaOH}-8.3 \mathrm{~mol} \% \mathrm{Na}_{2} \mathrm{CO}_{3} \text {, } \\
\mathrm{KOH}-9.3 \mathrm{~mol} \% \mathrm{~K}_{2} \mathrm{CO}_{3}, \\
\mathrm{KOH}-30 \mathrm{~mol} \% \mathrm{~K}_{2} \mathrm{CO}_{3}\end{array}$ & $\begin{array}{l}\text { Imitation } \\
\text { air }\end{array}$ & 50 & 5 & 50 & $573-973$ \\
\hline G & $\mathrm{C}_{6} \mathrm{H}_{3} \mathrm{Cl}_{3}$ & $\mathrm{KOH}-9.3 \mathrm{~mol} \% \mathrm{~K}_{2} \mathrm{CO}_{3}$ & $\begin{array}{l}\text { Imitation } \\
\text { air }\end{array}$ & 50 & 5 & $50-90$ & $673-973$ \\
\hline
\end{tabular}

tion. Concentration of $\mathrm{C}_{6} \mathrm{H}_{3} \mathrm{Cl}_{3}$ in the solution was 100 $\mathrm{mg} \cdot \mathrm{ml}^{-1}$.

Since molten salts used for the decomposition of chlorinated organic compound should be basic to absorb chlorine and has oxidizing ability to decompose organic components, the mixture of $\mathrm{KOH}(85 \%)$, Wako Pure Chemical Industries Ltd.) and $\mathrm{K}_{2} \mathrm{CO}_{3}(>99.5 \%$, Wako Pure Chemical Industries Ltd.) was used in this study. The eutectic mixture of $\mathrm{NaOH}$ (>97\%, Wako Pure Chemical Industries Ltd.) and $\mathrm{Na}_{2} \mathrm{CO}_{3}$ (>99.8\%, Wako Pure Chemical Industries Ltd.) was also used for comparison. Both $\mathrm{KOH}-\mathrm{K}_{2} \mathrm{CO}_{3}$ and $\mathrm{NaOH}-$ $\mathrm{Na}_{2} \mathrm{CO}_{3}$ systems show simple eutectic, ${ }^{9,10)}$ and their eutectic temperatures are 640 and $558 \mathrm{~K}$, respectively. The salts with eutectic composition (KOH-9.3 mol\% $\mathrm{K}_{2} \mathrm{CO}_{3}, \mathrm{NaOH}-8.3$ $\mathrm{mol} \% \mathrm{Na}_{2} \mathrm{CO}_{3}$ ) and $\mathrm{KOH}-30 \mathrm{~mol} \% \mathrm{~K}_{2} \mathrm{CO}_{3}$ (liquidus temperature: $760 \mathrm{~K}$ ) were used for the decomposition experiments. Moisture in the salts was removed by introducing argon during the melting for preparation prior to the decomposition experiment.

\subsection{Experimental Apparatus and Analysis}

Experimental apparatus and procedure were improved although essential principle is almost same to that previously reported. ${ }^{3)}$ The main improvement is to replace analytical equipment (from flame ionization detector to mass spectrometer) and to decrease detection limit of the organic compounds in the gas. The next is to employ a coaxial feeding tube devised in this study.

The representative experimental apparatus is shown in Fig. 1. The experimental conditions are summarized in Table 2 (Exp. series A to G). Chlorobenzen liquid or solution was fed with a syringe pump at the rate of $5 \mu 1 \cdot \mathrm{min}^{-1}$, and the imitation air $\left(\mathrm{N}_{2}-21 \% \mathrm{O}_{2}\right)$ or nitrogen was supplied by a mass flow controller at the rate of $25-400 \mathrm{ml} \cdot \mathrm{min}^{-1}$. The chlorobenzen liquid or solution was introduced into an inner tube (inner diameter: $0.90 \mathrm{~mm}$ ) of a coaxial stainless steel tubes, and the carrier gas was introduced into an outer tube (inner diameter: $2.84 \mathrm{~mm}$ ) of the coaxial tubes to be mixed with the sample liquid or solution. The injection rate of sample and the flow rate of imitation air were controlled independently. The sample immediately vaporizes on the tip of inner tube. The gas mixture was injected into the molten salts in a crucible (high purity alumina, 99.5\%, inner diameter: $20 \mathrm{~mm}$ ) at $573-973 \mathrm{~K}$ through a gas nozzle (high purity 
alumina, $99.5 \%$, inner diameter: $4 \mathrm{~mm}$ ). The gas nozzle has a hole (diameter: $1.4 \mathrm{~mm}$ ) at the end, and it was immersed in the molten salts in the depth of 50-90 mm from the surface level. The chlorobenzens introduced into the molten salts was estimated to form a bubble to be reacted with the molten salts during rising as Eqs. (1) and (2) under excess oxygen condition.

$$
\begin{gathered}
\mathrm{C}_{6} \mathrm{H}_{5} \mathrm{Cl}(g)+\mathrm{KOH}(l)+7 \mathrm{O}_{2}(g) \\
=\mathrm{KCl}(l)+3 \mathrm{H}_{2} \mathrm{O}(g)+6 \mathrm{CO}_{2}(g) \ldots \ldots \\
\Delta G^{\circ}{ }_{(1)}=-3223 \mathrm{~kJ} \text { at } 673 \mathrm{~K}^{14,15)} \\
\Delta G^{\circ}{ }_{(1)}=-3220 \mathrm{~kJ} \text { at } 973 \mathrm{~K}^{14,15)} \\
\mathrm{C}_{6} \mathrm{H}_{5} \mathrm{Cl}(g)+1 / 2 \mathrm{~K}_{2} \mathrm{CO}_{3}(l)+7 \mathrm{O}_{2}(g) \\
=\mathrm{KCl}(l)+5 / 2 \mathrm{H}_{2} \mathrm{O}(g)+13 / 2 \mathrm{CO}_{2}(g) . \\
\Delta G^{\circ}{ }_{(2)}=-3146 \mathrm{~kJ} \text { at } 673 \mathrm{~K}^{14,15)} \\
\Delta G^{\circ}{ }_{(2)}=-3172 \mathrm{~kJ} \text { at } 973 \mathrm{~K}^{14,15)}
\end{gathered}
$$

It was considered that the chlorine in chlorobenzens was trapped as $\mathrm{KCl}$ and the exhaust contains only $\mathrm{H}_{2} \mathrm{O}$ and $\mathrm{CO}_{2}$. Similar reactions were expected for sodium salt. It was also expected that the trimethylpentane solvent was converted to $\mathrm{H}_{2} \mathrm{O}$ and $\mathrm{CO}_{2}$ by reacting with oxygen in the carrier gas. The ratio of the oxygen to the solution injected was about 1.241.45 times of stoichiometry for the complete decomposition reaction. The exhaust was extracted from an exhaust tube by using a gas tight syringe, and the residual concentration of chlorobenzens and the by-products were analyzed by a gas chromatography mass spectrometer (Shimazu Co., GCMSQP2010). The decomposition efficiency, $\varepsilon$ was determined by Eq. (3).

$$
\mathcal{E}=\left(1-C_{\mathrm{E}} / C_{\mathrm{I}}\right) \times 100 .
$$

where $C_{\mathrm{E}}$ and $C_{\mathrm{I}}$ indicate the concentrations of chlorobenzens in the exhaust and in the feed gas, respectively. The concentration indicates the volume fraction (vol-ppm) of chemicals in the carrier gas at $25^{\circ} \mathrm{C}$ under $1 \mathrm{~atm}$.

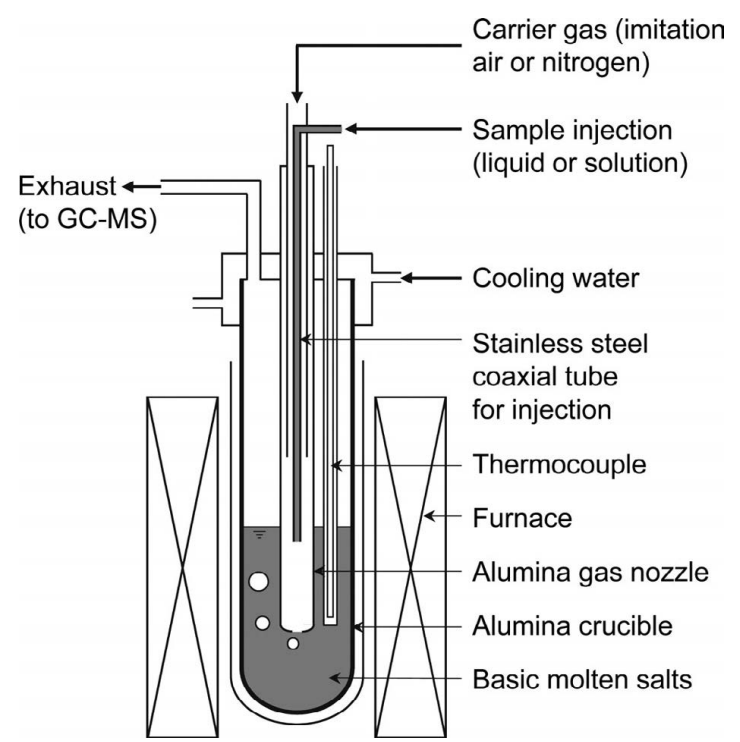

Fig. 1. Experimental apparatus for the decomposition of chlorobenzenes by using basic molten salts.

\section{Results and Discussion}

\subsection{Oxidation of $\mathrm{C}_{6} \mathrm{H}_{5} \mathrm{Cl}$ without Molten Salts (Exp. Series A)}

The influence of the decomposition of chlorobenzens by the imitation air was preliminary checked prior to the experiment by molten salts. The initial concentration of $\mathrm{C}_{6} \mathrm{H}_{5} \mathrm{Cl}$ in the gas fed was $26600 \mathrm{ppm}$. The residual concentration of $\mathrm{C}_{6} \mathrm{H}_{5} \mathrm{Cl}$ after the thermal decomposition is shown in Fig. 2. The concentration decreased to $1200-1400 \mathrm{ppm}$. This corresponds to the decomposition efficiency of $95 \%$. Namely, decomposition by the air was not enough for complete decomposition.

In the qualitative analysis, some by-products were found. Figure 3 shows the concentration of by-products (benzene, oxalyl chloride and phosgene) in the exhaust, where the concentrations of oxalyl chloride and phosgene are expressed in arbitrary unit because of the difficult calibration. The chlo-

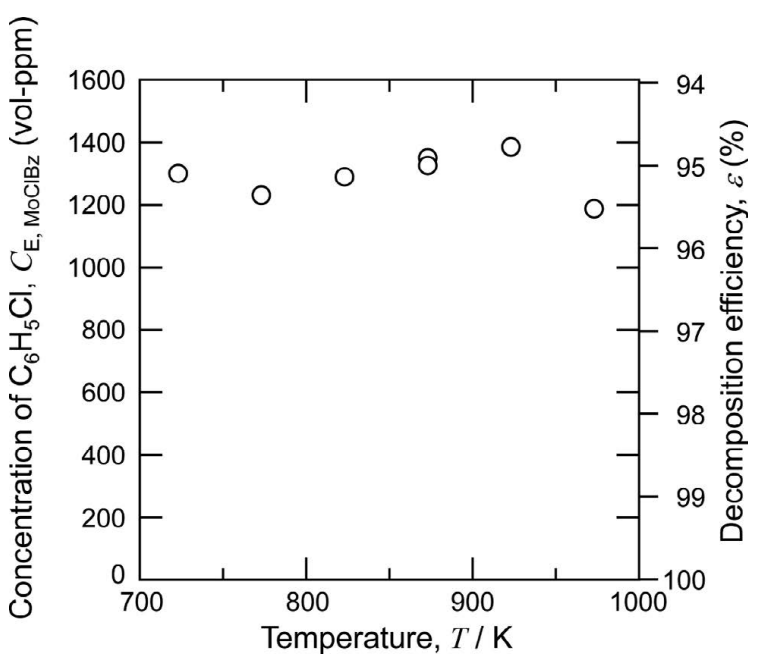

Fig. 2. The residual concentration of $\mathrm{C}_{6} \mathrm{H}_{5} \mathrm{Cl}$ in the exhaust after the thermal decomposition without molten salts. Carrier gas: imitation air, injection rate of $\mathrm{C}_{6} \mathrm{H}_{5} \mathrm{Cl}: 5 \mathrm{ml} \cdot \mathrm{min}^{-1}$, flow rate of imitation air: $50 \mathrm{ml} \cdot \mathrm{min}^{-1}$, initial concentration of $\mathrm{C}_{6} \mathrm{H}_{5} \mathrm{Cl}: 26600 \mathrm{ppm}$.

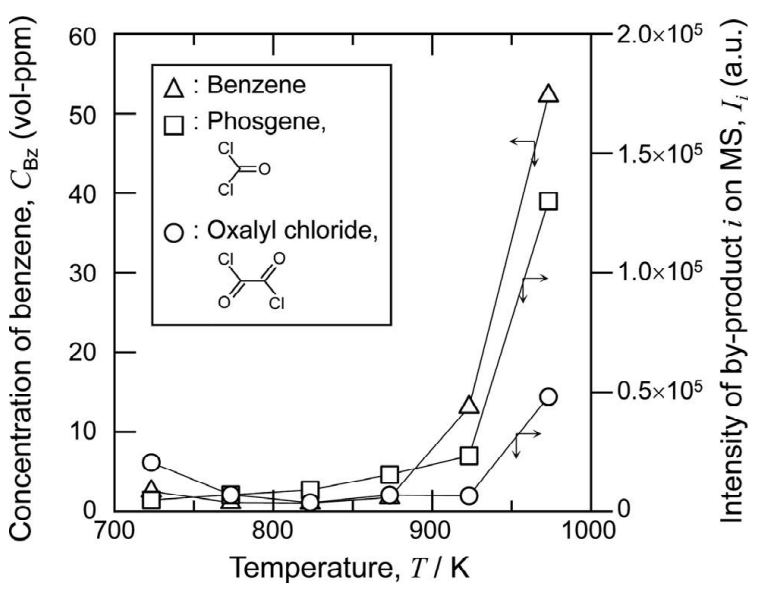

Fig. 3. The concentration of benzene by-product in the exhaust after the thermal decomposition of $\mathrm{C}_{6} \mathrm{H}_{5} \mathrm{Cl}$. Intensities of by-product phosgene $\left(\mathrm{COCl}_{2}\right)$ and oxalyl chloride $\left(\mathrm{C}_{2} \mathrm{O}_{2} \mathrm{Cl}_{2}\right)$ on mass spectrum are also shown. Carrier gas: imitation air, injection rate of $\mathrm{C}_{6} \mathrm{H}_{5} \mathrm{Cl}: 5 \mathrm{ml} \cdot \mathrm{min}^{-1}$, flow rate of imitation air: $50 \mathrm{ml} \cdot \mathrm{min}^{-1}$. 
rinated compounds increased with increasing temperature, which indicates the possibility of formation of harmful chlorinated compounds due to the absence of chlorine absorber. The increase of benzene may also be formed by the decomposition of $\mathrm{C}_{6} \mathrm{H}_{5} \mathrm{Cl}$. Consequently, simple oxidation at moderate temperature was not sufficient for the complete destruction of $\mathrm{C}_{6} \mathrm{H}_{5} \mathrm{Cl}$.

\subsection{Decomposition of $\mathrm{C}_{6} \mathrm{H}_{5} \mathrm{Cl}$ by Molten Salts under Oxidative Atmosphere (Exp. Series B)}

The residual concentration of $\mathrm{C}_{6} \mathrm{H}_{5} \mathrm{Cl}$ in the exhaust after the decomposition by molten salts (KOH-9.3 mol\% $\mathrm{K}_{2} \mathrm{CO}_{3}$, $\mathrm{KOH}-30 \mathrm{~mol} \% \mathrm{~K}_{2} \mathrm{CO}_{3}$ and $\mathrm{NaOH}-8.3 \mathrm{~mol} \% \mathrm{Na}_{2} \mathrm{CO}_{3}$ ) is shown in Fig. 4. The decomposition efficiency is also shown on right ordinate in the figure. The feed rates of $\mathrm{C}_{6} \mathrm{H}_{5} \mathrm{Cl}$ liquid and imitation air were same as those in thermal decomposition. As shown in Fig. 4, the concentration of $\mathrm{C}_{6} \mathrm{H}_{5} \mathrm{Cl}$ decreased to less than $0.25 \mathrm{ppm}$, and the decomposition efficiency more than $99.999 \%$ was established in any molten salts. The efficiency, especially in $\mathrm{KOH}$ based salts, reached to very high of $99.9999 \%$ in a certain condition. $\mathrm{KOH}-9.3 \mathrm{~mol} \% \mathrm{~K}_{2} \mathrm{CO}_{3}$ and $\mathrm{KOH}-30 \mathrm{~mol} \% \mathrm{~K}_{2} \mathrm{CO}_{3}$ showed nearly same, and $\mathrm{NaOH}-8.3 \mathrm{~mol} \% \mathrm{Na}_{2} \mathrm{CO}_{3}$ showed relatively low decomposition efficiency. This may be because the driving force of decomposition reaction in $\mathrm{NaOH}$ based salt is slightly smaller than that in $\mathrm{KOH}$ based salts (see the standard Gibbs energy changes of Eqs. (1) and (5) for comparison).

$$
\begin{gathered}
\mathrm{C}_{6} \mathrm{H}_{5} \mathrm{Cl}(g)+\mathrm{NaOH}(l)+7 \mathrm{O}_{2}(g) \\
=\mathrm{NaCl}(l)+3 \mathrm{H}_{2} \mathrm{O}(g)+6 \mathrm{CO}_{2}(g) \ldots . . . \\
\Delta G^{\circ}{ }_{(5)}=-3201 \mathrm{~kJ} \text { at } 673 \mathrm{~K}^{14,15)} \\
\Delta G^{\circ}{ }_{(5)}=-3202 \mathrm{~kJ} \text { at } 973 \mathrm{~K}^{14,15)} \\
\mathrm{C}_{6} \mathrm{H}_{5} \mathrm{Cl}(g)+1 / 2 \mathrm{Na}_{2} \mathrm{CO}_{3}(l)+7 \mathrm{O}_{2}(g) \\
=\mathrm{NaCl}(l)+5 / 2 \mathrm{H}_{2} \mathrm{O}(g)+13 / 2 \mathrm{CO}_{2}(g) . \\
\Delta G^{\circ}{ }_{(6)}=-3115 \mathrm{~kJ} \text { at } 673 \mathrm{~K}^{14,15)} \\
\Delta G^{\circ}{ }_{(6)}=-3146 \mathrm{~kJ} \text { at } 973 \mathrm{~K}^{14,15)}
\end{gathered}
$$

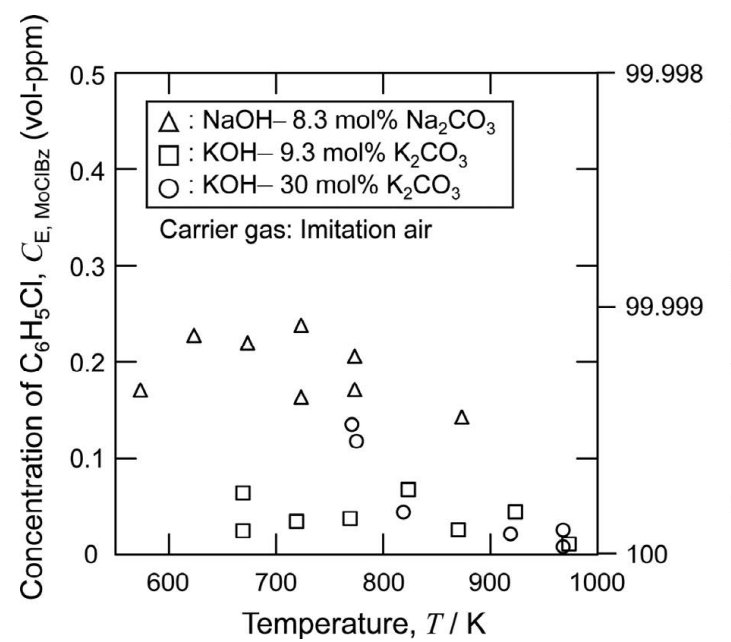

Fig. 4. The residual concentration of $\mathrm{C}_{6} \mathrm{H}_{5} \mathrm{Cl}$ in the exhaust after the decomposition by molten salts. Decomposition efficiency is also indexed on right ordinate. Carrier gas: imitation air, injection rate of $\mathrm{C}_{6} \mathrm{H}_{5} \mathrm{Cl}: 5 \mathrm{ml} \cdot \mathrm{min}^{-1}$, flow rate of imitation air: $50 \mathrm{ml} \cdot \mathrm{min}^{-1}$, immersion depth of gas nozzle: $50 \mathrm{~mm}$.

\subsection{Decomposition of $\mathrm{C}_{6} \mathrm{H}_{5} \mathrm{Cl}$ by Molten Salts under No Oxidative Atmosphere (Exp. Series C)}

Figure 5 shows the results of decomposition by replacing the carrier gas with nitrogen which has no oxidative ability. The concentration decreased to less than $0.2 \mathrm{ppm}$ as well as by using imitation air. However, the formation of many simple organic by-products such as $n$-Ethylformamide, 3-Methoxy-3-methyl-2butanone, 2-Methoxy-2-methyl-propane, 1,3-Dioxolane, 3-Methoxy-pentane and 1-Hpten-4-ol (see Table 3 for structural formula of by-products) were found by the qualitative analysis of GC-MS. Such compounds do not contain chlorine. Since the above by-products were not detected in the experiment by using imitation air, oxygen gas was found to be indispensable for the complete destruction of organic by-products.

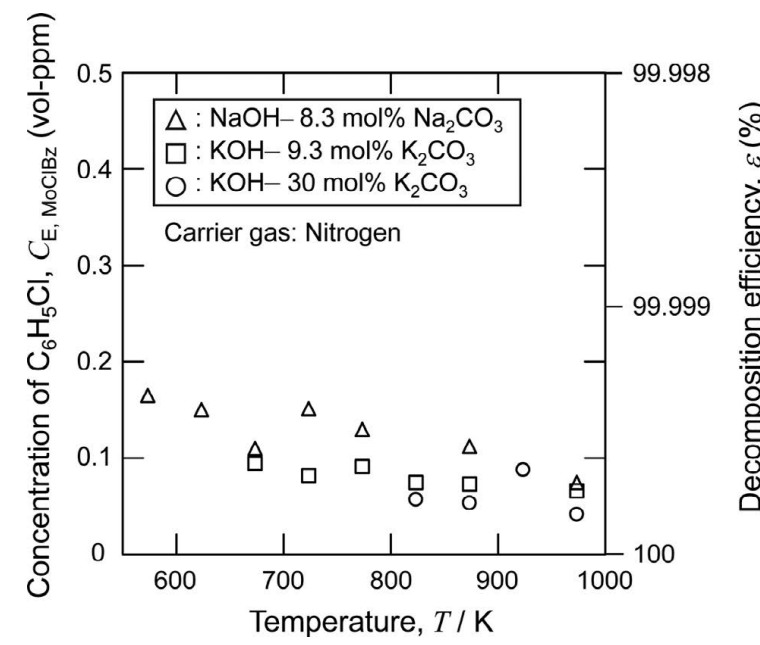

Fig. 5. The residual concentration of $\mathrm{C}_{6} \mathrm{H}_{5} \mathrm{Cl}$ in the exhaust after the decomposition by molten salts. Decomposition efficiency is also indexed on right ordinate. Carrier gas: nitrogen injection rate of $\mathrm{C}_{6} \mathrm{H}_{5} \mathrm{Cl}: 5 \mathrm{ml} \cdot \mathrm{min}^{-1}$, flow rate of nitrogen: $50 \mathrm{ml} \cdot \mathrm{min}^{-1}$, immersion depth of gas nozzle: 50 $\mathrm{mm}$.

Table 3. Representative by-products formed after the decomposition of $\mathrm{C}_{6} \mathrm{H}_{5} \mathrm{Cl}$ fed with nitrogen.

Name of substance




\subsection{Influence of Gas Flow Rate for Decomposition of $\mathrm{C}_{6} \mathrm{H}_{5} \mathrm{Cl}$ (Exp. Series D)}

The influence of flow rate of gas mixture under the constant concentration of $\mathrm{C}_{6} \mathrm{H}_{5} \mathrm{Cl}$ is shown in Fig. 6. The concentration of benzene as a by-product is also shown in the figure. The initial sample concentration was $26600 \mathrm{ppm}$. The residual concentration of $\mathrm{C}_{6} \mathrm{H}_{5} \mathrm{Cl}$ was almost constant typically less than $0.1 \mathrm{ppm}$ at the flow rate of $50-250$

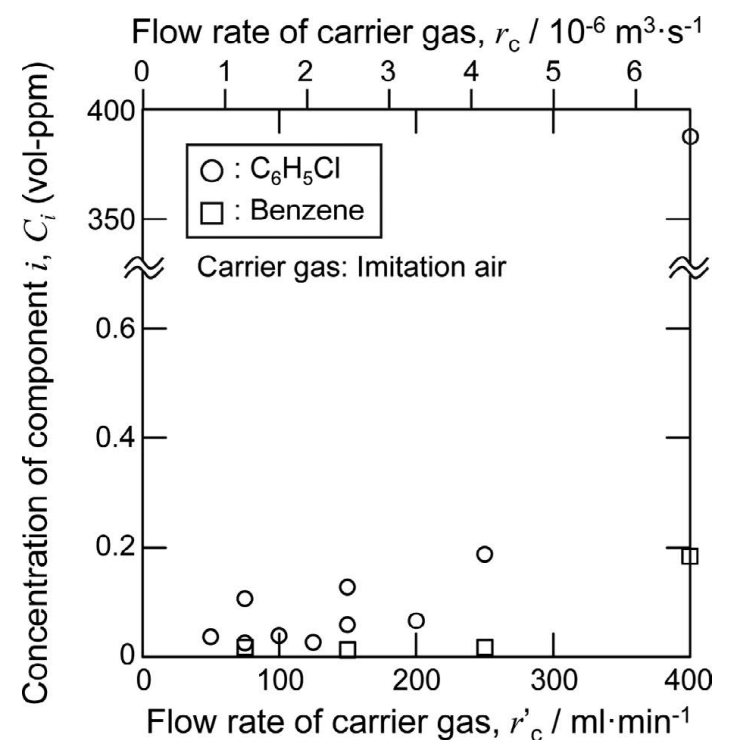

Fig. 6. The residual concentration of $\mathrm{C}_{6} \mathrm{H}_{5} \mathrm{Cl}$ and by-product benzene in the exhaust after the decomposition by molten salts. Salt: $\mathrm{KOH}-30 \mathrm{~mol} \% \mathrm{~K}_{2} \mathrm{CO}_{3}$, carrier gas: imitation air, injection rate of $\mathrm{C}_{6} \mathrm{H}_{5} \mathrm{Cl} /$ flow rate of imitation air $=1$ / 10000 , immersion depth of gas nozzle: $50 \mathrm{~mm}$, reaction temperature: $873 \mathrm{~K}$.

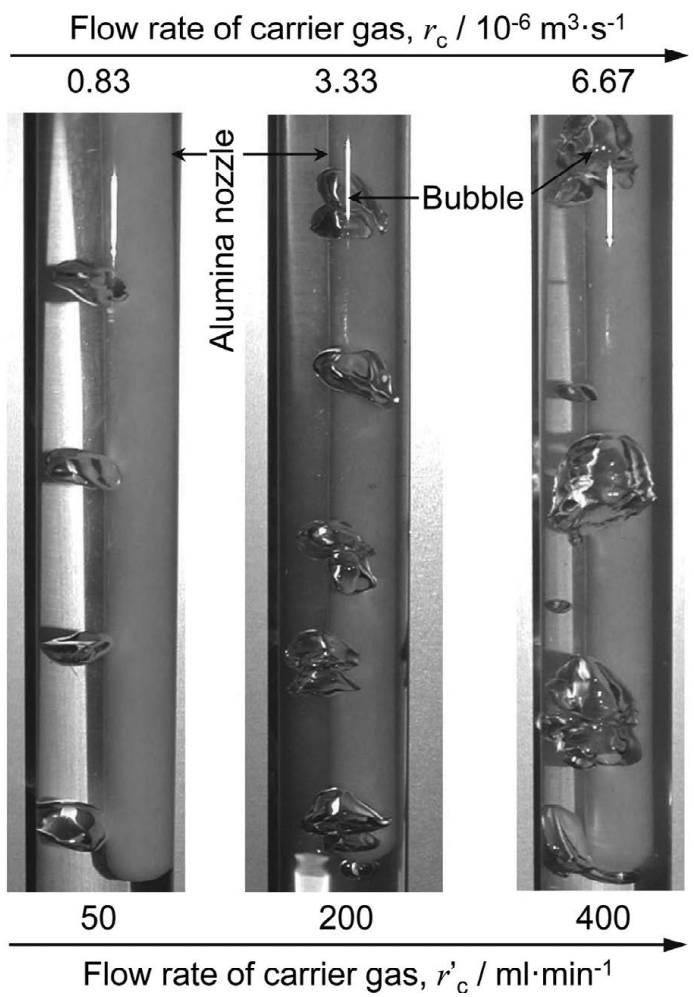

Fig. 7. Photograph of bubble formed in the water model experiment for the observation of bubble formation and growth. Diameter of hole on the end of gas nozzle: $1.4 \mathrm{~mm}$. $\mathrm{ml} \cdot \mathrm{min}^{-1}$, but drastically increased to $380 \mathrm{ppm}$ at 400 $\mathrm{ml} \cdot \mathrm{min}^{-1}$. This suggests that the increase of flow rate drastically changed the mass transfer effect between bubble and molten salts. The benzene by-product was almost under 0.02 $\mathrm{ppm}$ at the flow rate of $50-250 \mathrm{ml} \cdot \mathrm{min}^{-1}$, which indicates that benzene as an intermediate product after the dechrolination is not stable or intermediate benzene is promptly decomposed to simpler compounds under the condition investigated.

The water model experiment was conducted in order to estimate the manner of formation and growth of bubble in molten salts. Because the kinematic viscosity of molten $\mathrm{KOH}-\mathrm{K}_{2} \mathrm{CO}_{3}$ is close to that of water, ${ }^{16,17)}$ similar behavior for bubble formation and growth is expected. The photograph of bubble formed in the water model experiment is shown in Fig. 7. When the flow rate of gas was slow, small bubbles formed on the tip of gas nozzle were detached and lifted independently. On the other hand, the diameter of unit bubble significantly increased and furthermore coalesced each other during the lifting when the flow rate of gas was fast, which gave the formation of large bubble. This phenomenon caused the increase of diffusion length of reactant in bubble and the decrease of specific surface area of the bubble, which may be the reason of drastic increase of residual $\mathrm{C}_{6} \mathrm{H}_{5} \mathrm{Cl}$ when the flow rate was increased.

\subsection{Influence of Initial Concentration for Decomposi- tion of $\mathrm{C}_{6} \mathrm{H}_{5} \mathrm{Cl}$ (Exp. Series E)}

The influence of concentration of $\mathrm{C}_{6} \mathrm{H}_{5} \mathrm{Cl}$ fed under constant flow rate of carrier gas is shown in Fig. 8. The initial concentration was $26600-532000$ ppm- $\mathrm{C}_{6} \mathrm{H}_{5} \mathrm{Cl}$. The stoichiometry for the complete decomposition is established when the initial concentration of $\mathrm{C}_{6} \mathrm{H}_{5} \mathrm{Cl}$ is $36200 \mathrm{ppm}$. The residual concentration of $\mathrm{C}_{6} \mathrm{H}_{5} \mathrm{Cl}$ gradually increased with increasing the initial concentration but suddenly increased to $60 \mathrm{ppm}$ (not shown in the figure) when the $\mathrm{C}_{6} \mathrm{H}_{5} \mathrm{Cl}$ fed was $532000 \mathrm{ppm}$. The concentration of benzene as by-prod-

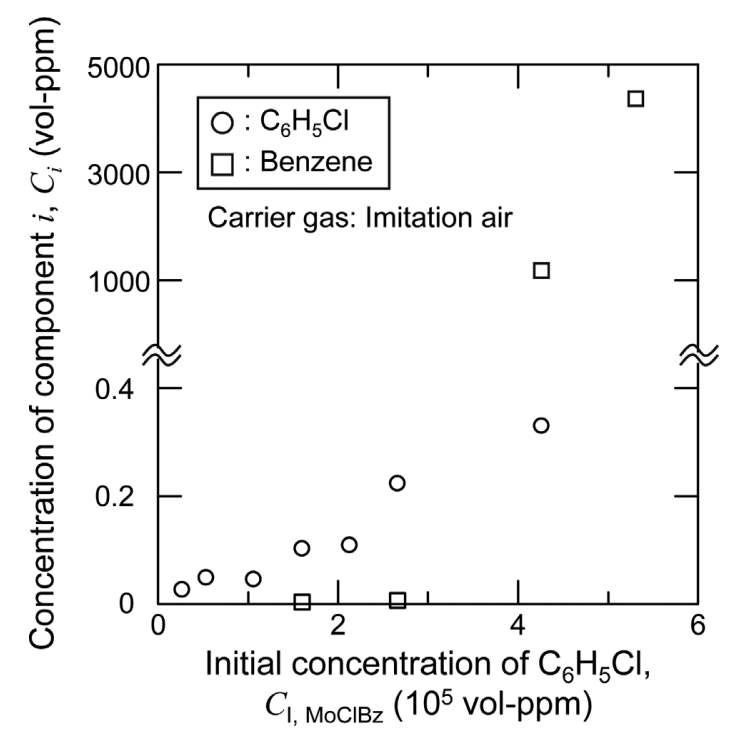

Fig. 8. The residual concentration of $\mathrm{C}_{6} \mathrm{H}_{5} \mathrm{Cl}$ and by-product benzene in the exhaust after the decomposition by molten salts. Salt: $\mathrm{KOH}-30 \mathrm{~mol} \% \mathrm{~K}_{2} \mathrm{CO}_{3}$, carrier gas: imitation air, flow rate of imitation air: $25 \mathrm{ml} \cdot \mathrm{min}^{-1}$, immersion depth of gas nozzle: $50 \mathrm{~mm}$, reaction temperature: $873 \mathrm{~K}$. 


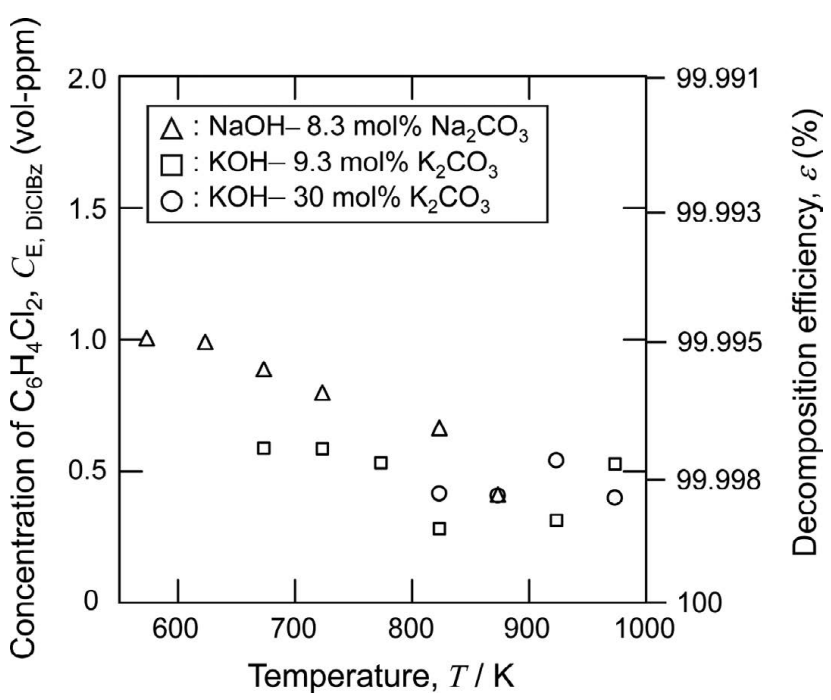

Fig. 9. The residual concentration of $\mathrm{C}_{6} \mathrm{H}_{4} \mathrm{Cl}_{2}$ in the exhaust after the decomposition by molten salts. Carrier gas: imitation air, injection rate of $\mathrm{C}_{6} \mathrm{H}_{4} \mathrm{Cl}_{2}: 5 \mathrm{ml} \cdot \mathrm{min}^{-1}$, flow rate of imitation air: $50 \mathrm{ml} \cdot \mathrm{min}^{-1}$, immersion depth of gas nozzle: 50 $\mathrm{mm}$.

uct was also drastically increased to $1200 \mathrm{ppm}$ when the concentration of $\mathrm{C}_{6} \mathrm{H}_{5} \mathrm{Cl}$ fed was 425000 ppm. This means that chlorine was promptly extracted but benzene ring was not destructed under less supply of $\mathrm{O}_{2}$. Furthermore, byproducts comprising benzene ring, such as naphthalene and biphenyl, diethyl ether and dibenzofuran were also detected under less supply of $\mathrm{O}_{2}$ by the qualitative analysis. These results indicate that the lack of oxygen caused the incomplete destruction of organic compounds.

\subsection{Decomposition of $\mathrm{C}_{6} \mathrm{H}_{5} \mathrm{Cl}_{2}$ by Molten Salts under Oxidative Atmosphere (Exp. Series F)}

As described above, it was found that $\mathrm{C}_{6} \mathrm{H}_{5} \mathrm{Cl}$ was destructed at high decomposition efficiency under the excess oxygen condition. Based on the results, the decomposition of dichlorobenzene was conducted. Figure 9 shows the results of decomposition of $\mathrm{C}_{6} \mathrm{H}_{4} \mathrm{Cl}_{2}$ by using imitation air. The initial concentration of $\mathrm{C}_{6} \mathrm{H}_{4} \mathrm{Cl}_{2}$ in gas mixture was 21700 ppm. $\mathrm{NaOH}-8.3 \mathrm{~mol} \% \mathrm{Na}_{2} \mathrm{CO}_{3}$ salt showed relatively low decomposition efficiency, but the efficiencies were higher than 99.995\%. Furthermore, $\mathrm{KOH}-9.3 \mathrm{~mol} \% \mathrm{~K}_{2} \mathrm{CO}_{3}$ salt showed very high decomposition efficiency over than $99.999 \%$ in a certain condition. Namely, the decomposition efficiency by using $\mathrm{KOH}$ based salt was slightly higher than that by using $\mathrm{NaOH}$ based salt, which was almost same result as the decomposition of monochlorobenzen.

\subsection{Decomposition of $\mathrm{C}_{6} \mathrm{H}_{5} \mathrm{Cl}_{3}$ by Molten Salts under Oxidative Atmosphere (Exp. Series G)}

Figure 10 shows the results of decomposition of $\mathrm{C}_{6} \mathrm{H}_{3} \mathrm{Cl}_{3}$ conducted as the same manner. The initial concentration of $\mathrm{C}_{6} \mathrm{H}_{3} \mathrm{Cl}_{3}$ fed in gas mixture was $1120 \mathrm{ppm}$. The immersion depth of gas nozzle was changed from 50 to $90 \mathrm{~mm}$. The decomposition efficiency increased with increasing the immersion depth at $673 \mathrm{~K}$. The decomposition efficiencies under the different immersion depth were almost same at $873 \mathrm{~K}$. Consequently, the chlorobenzene containing three chlorine atoms was also decomposed at very high efficiency.

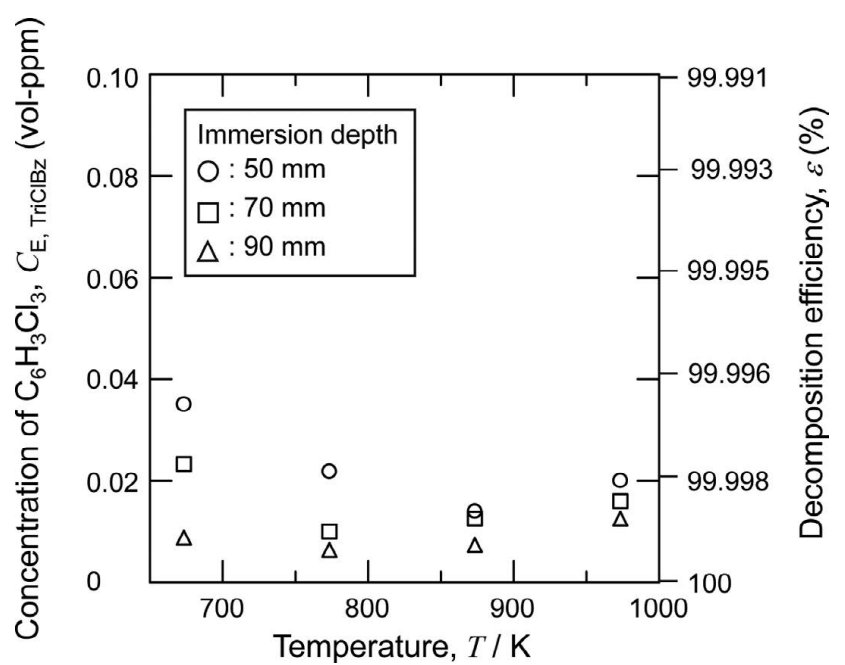

Fig. 10. The residual concentration of $\mathrm{C}_{6} \mathrm{H}_{3} \mathrm{Cl}_{3}$ in the exhaust after the decomposition by molten salts. Salt: $\mathrm{KOH}-9.3 \mathrm{~mol} \%$ $\mathrm{K}_{2} \mathrm{CO}_{3}$, carrier gas: imitation air, injection rate of $\mathrm{C}_{6} \mathrm{H}_{3} \mathrm{Cl}_{3}$ solution: $5 \mathrm{ml} \cdot \mathrm{min}^{-1}$, flow rate of imitation: $50 \mathrm{ml} \cdot \mathrm{min}^{-1}$.

From this study, it was found that the decomposition efficiency of chlorobenzenes was drastically increased by using basic molten salts under the excess oxygen conditions compared with no oxygen condition. This new process was also very effective for complete decomposition of chlorobenzene containing multiple chlorine atoms. Practical decomposition process for PCBs such as the dechlorination by the reaction with metallic sodium needs multi step treatment for complete decomposition. But the decomposition process in this study can serve the higher degree decomposition to $\mathrm{CO}_{2}$ and $\mathrm{H}_{2} \mathrm{O}$ at one step. This is big advantage, and this new technology is hopeful for constructing safe and efficient waste treatment system of PCBs.

\section{Conclusions}

The decomposition of mono, di and tri-chlorobenzenes as the imitation substance of PCBs was investigated by using molten $\mathrm{KOH}-\mathrm{K}_{2} \mathrm{CO}_{3}$ and molten $\mathrm{NaOH}-\mathrm{Na}_{2} \mathrm{CO}_{3}$ maintained at 573-973 K with imitation air. The decomposition efficiency reached to very high of $99.9999 \%$ in an optimum condition. The efficiency of chlorobenzenes was affected by the flow rate of imitation air, and the initial concentration of chlorobenzen fed in gas mixture. The excess oxygen condition is required for the complete decomposition for benzene derivatives. From a series of systematic study, the effectiveness of basic molten salts for the decomposition of simple chlorinated organic compounds comprising benzene derivative was demonstrated.

\section{Acknowledgement}

The authors are grateful to Emeritus Professor Syukuji Aasakura of the Yokohama National University for his valuable discussions throughout this project. This work was financially supported by a Grant-in-Aid for Scientific Research (A) (No. 15206082) from the Ministry of Education, Culture, Sports, Science and Technology, Japan (MEXT). 


\section{REFERENCES}

1) Haikibutsu Handbook, ed. by Japan Society of Material Cycles and Waste Management, Ohmsha, Tokyo, Japan, (1997), 975.

2) Ministry of Environment of Japan: Kankyo Hakusyo, Nikkei Insatsu, Tokyo, Japan, (2010), 262.

3) Y. Yamauchi, O. Takeda, M. Hoshi, T. Yamamura and Y. Sato: Electrochemistry, submitted.

4) M. Hiraoka: Nippon Kagaku Kaishi, 5 (1991), 559.

5) H. Tachikawa, N. Yoshimoto and T. Kodama: J. Jpn. Assoc. Odor Envir., 36 (2005), 331.

6) Y. Yukio and T. Otsuka: Japan Patent, P2002-187858A.

7) T. Kawai: Resour. Process., 47 (2000), 17.

8) P. H. Howard and W. M. Meylan: Handbook of Physical Properties of Organic Chemicals, CRC press, Boca Raton, USA, (1997), 95, $123,191,378$

9) L. P. Cook and H. F. McMurdi: Phase Diagrams for Ceramists, Vol. VII, The American Ceramic Society Inc., Westerville, OH, (1989),
63

10) L. P. Cook and H. F. McMurdie: Phase Diagrams for Ceramists, Vol. VII, The American Ceramic Society Inc., Westerville, OH, (1989), 68 .

11) K. Nakahara: Dictionary of Inorganic Compounds \& Complexes, Kodan-sya, Tokyo, (1997), 405, 411,463.

12) S. Nagakura: Rikagaku Jiten, 5th ed., Iwanami syoten, Tokyo, (1998), 814.

13) J. I. Kroschwitz: Encyclopedia of chemical technology, 4th ed., Vol. 1, Wiley, New York, (1991), 1025.

14) I. Barin: Thermochemical Data of Pure Substances, VCH Verlagsgesellschaft mbH, Weinheim, Germany, (1989).

15) E. S. Domalski and E. D. Hearing: J. Phys. Chem. Ref. Data, 22 (1993), 805.

16) Thermophysical Properties Handbook, ed. by Japan Society of Thermophysical Properties, Yokendo, Tokyo, (2008), 43.

17) G. J. Janz: Molten Salts Handbook, Academic Press, New York, USA, (1967). 